\title{
Baby-friendly hospitals in Turkey: evaluation of adherence to the Ten Steps to Successful Breastfeeding
}

Nilgün Çaylan, ${ }^{1}$ Melek Kiliç, ${ }^{1}$ Sıddıka Yalçin, ${ }^{2}$ Başak Tezel ${ }^{1}$ and Fatih Kara ${ }^{3}$

${ }^{1}$ Ministry of Health, Department of Child and Adolescents Health, Ankara, Turkey (Correspondence to: N. Çaylan: nilgun.caylan@gmail.com). ${ }^{2}$ Hacettepe University Faculty of Medicine, Department of Pediatrics, Division of Social Pediatrics, Ankara, Turkey. ${ }^{3}$ Ministry of Health, General Directorate of Public Health, Ankara, Turkey

\begin{abstract}
Background: The Baby-Friendly Hospital Initiative (BFHI) is a World Health Organization and United Nations Children's Fund joint global programme to protect, promote and support breastfeeding. Sustainability of the BFHI standards is important for health facilities and country-level implementation.

Aims: To analyse the 2018-2019 external reassessment results of baby-friendly hospitals (BFHs) in Turkey.

Methods: We included 414 BFHs. The Ten Steps to Successful Breastfeeding were divided into 2 groups: critical management procedures (Steps 1 and 2) and key clinical practices (Steps 3-10).

Results: All 10 steps were fulfilled by $60.1 \%$ of the hospitals. Steps 3 and 2 had the lowest compliance rates (81.6\% and 85.7\%), and Steps 7 and 8 had the highest rates (97.1\% and 98.1\%). Caesarean section rates in the fourth quartile were associated with significantly lower adherence to Steps 3 and 10. The presence of another external reassessment within 5 years was associated with a significantly higher adherence rate to Step 3, and a significantly higher full implementation rate for the clinical practices. Hospitals that fully implemented management procedures had a significantly higher fulfilment percentage for all clinical practices. The western region had higher adherence rates for all the clinical practices than other regions.

Conclusion: Reassessments seem useful for sustainability. Full compliance with Steps 1 and 2 is important for higher adherence to the clinical steps. Regional variations should be taken into account in the implementation of the programme. Keywords: Baby-Friendly Hospital Initiative, Ten Steps to Successful Breastfeeding, International Code of Marketing of Breastmilk Substitutes, reassessment, adherence rate, Turkey

Citation: Çaylan N; Kiliç M; Yalçin S; Tezel B; Kara F. Baby-friendly hospitals in Turkey: evaluation of adherence to the Ten Steps to Successful Breastfeeding. East Mediterr Health J. 2022;28(5):352-361. https://doi.org/10.26719/emhj.22.021

Received: 21/04/21; accepted: 04/11/21

Copyright @ World Health Organization (WHO) 2022. Open Access. Some rights reserved. This work is available under the CC BY-NC-SA 3.0 IGO license (https://creativecommons.org/licenses/by-nc-sa/3.0/igo)
\end{abstract}

\section{Introduction}

Breastfeeding is the best nutritional choice for child health and development (1-4). The Baby-Friendly Hospital Initiative (BFHI) is a World Health Organization (WHO) and United Nations Children's Fund (UNICEF) joint global programme initiated in 1991 to protect, promote and support breastfeeding. The Ten Steps to Successful Breastfeeding (the Ten Steps) and the International Code of Marketing of Breastmilk Substitutes (the Code) are core components of the BFHI $(5,6)$. The guidelines and the Ten Steps were updated in 2009 and $2018(5,7,8)$ (Table 1). In 2018 , countries were called on to implement nine key responsibilities for sustainability (5) (Table 2).

To support breastfeeding, the BFHI certifies health facilities that fulfil the requirements. The Ten Steps has a positive effect on breastfeeding outcomes $(9,10)$. A systematic review demonstrated that adherence to the Ten Steps improves breastfeeding indicators (early initiation of breastfeeding, exclusive breastfeeding and the continuation of breastfeeding) (9).

The BFHI was launched in Turkey with the collaboration of the Ministry of Health $(\mathrm{MoH})$ and
UNICEF in 1991. The programme progressed gradually, and by the end of 2019, there were 1309 BFHs (1095 of which are active: 534 private hospitals, 453 secondary care public hospitals, 66 university hospitals, 36 tertiary care public hospitals, and 6 other hospitals). Approximately $98 \%$ of all births in Turkey take place in BFHs (11). The BFHI has contributed to the improvement of breastfeeding rates. According to the recent Turkey Demographic and Health Survey, 98\% of children are breastfed at some point in their lives (12). The median duration of breastfeeding increased from 12 months in 1993 to 16.7 months in 2018. The percentage of exclusive breastfeeding in infants aged $<6$ months increased from $10.4 \%$ in 1993 to $40.7 \%$ in 2018 . Breastfeeding within the first hour after delivery increased from $19.9 \%$ in 1993 to $71.0 \%$ in 2018 (12).

Sustainability of the achieved BFHI standards is important for health facilities and country-level implementation. The objective of this study was to analyse the 2018 and 2019 external reassessment results of BFHs in Turkey, and to contribute to the monitoring of the BFHI. 


\section{Methods}

\section{Study design}

This study was a descriptive cross-sectional reassessment of BFHs between 1 January 2018 and 31 December 2019.

\section{Reassessment process and data collection}

According to WHO guidelines, after an internal evaluation, facilities should be assessed by an external team. The term external assessment is generally used for the initial certification process, while external reassessment describes the post-certification evaluation of previously certified healthcare facilities. According to the guidelines, certified facilities should be evaluated through self-appraisal annually and by an external team triennially $(7,13)$. In Turkey, BFHs evaluate themselves annually using the self-assessment form that allows a health facility to check its own practices. External assessments/ reassessment processes are coordinated by the Child and Adolescent Health Department (CAHD) in collaboration with the provincial health directorates of 81 provinces. External assessments/reassessments are performed by national assessment team members (national assessors), who are volunteer health workers. They are trained on 2 courses totalling 40 hours (20 hours on BHFI practices and 20 hours on BFHI assessment tools).

Hospitals are evaluated using a 10-step-based tool adapted from revised WHO/UNICEF materials $(5,13)$ (Table 1). The 2018 revision states that the "full application of the International Code of Marketing of Breastmilk Substitutes and relevant World Health Assembly Resolutions" and "establishing ongoing monitoring and data management systems have been integrated into Step 1". BFHI steps have been divided into 2 groups: critical management procedures (Steps 1 and 2) and key clinical practices (Steps 3-10) (Table 1) (5). This study was designed and presented according to the current version of the Ten Steps (5).

During hospital assessment/reassessment, national assessors interview staff who work with pregnant women, mothers, or babies, as well as pregnant women and mothers regarding the care they received at the facility (13). Questionnaires and observations are recorded on forms and then transferred to summary sheets.

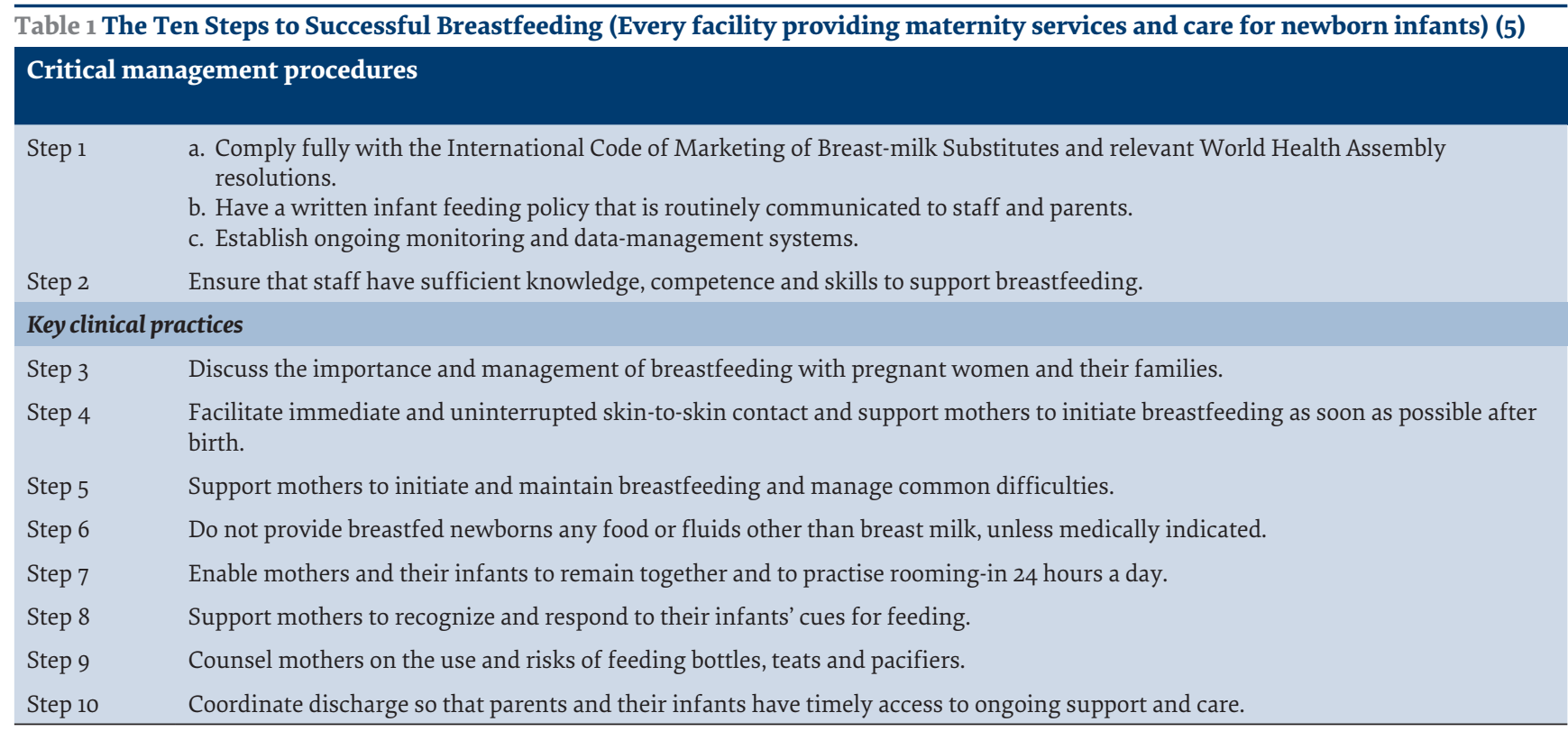

\begin{tabular}{ll}
\hline Table $\mathbf{2}$ Nine key responsibilities of a national BFHI programme (5) \\
\hline 1. & Establish or strengthen a national breastfeeding coordination body. \\
2. & Integrate the Ten Steps into relevant national policy documents and professional standards of care. \\
3. & Ensure the competency of health professionals and managers in implementation of the Ten Steps. \\
4. & Utilize external assessment systems to regularly evaluate adherence to the Ten Steps. \\
5. & Develop and implement incentives for compliance and/or sanctions for non-compliance with the Ten Steps. \\
6. & Provide technical assistance to facilities that are making changes to adopt the Ten Steps. \\
7. & Monitor implementation of the Initiative. \\
8. & Advocate for the BFHI to relevant audiences. \\
9. & Identify and allocate sufficient resources to ensure the ongoing funding of the Initiative. \\
\hline
\end{tabular}


Information about hospitals is reported on the front pages of the assessment tool and includes: hospital name and type, initial certification date, assessment date, number of births and percentage of caesarean deliveries in the previous year, number and characteristics of staff working in maternity clinics, distribution of patients hospitalized in maternity and neonatal clinics, and breastfeeding indicators (exclusive breastfeeding at hospital stay, breastfeeding at discharge, and bottle feeding) obtained from the hospital's own records. The assessment results for each of the Ten Steps are recorded as passed or failed for the facility, on the final summary sheet (13). The lead assessor sends the assessment file to the CAHD. The final decision about the assessment/ reassessment of the facilities is taken by the National
Breastfeeding Committee. The Committee consists of academics from universities and training and research hospitals, representatives of paediatrics, obstetrics and midwifery associations, national assessment team members, field workers and representatives of nongovernmental organizations, and ministries (Figure 1). According to the rule established by the National Breastfeeding Committee, if a health facility does not meet the requirements for $\leq 5$ of the Ten Steps, a 3-6-month period is granted to the facility to take corrective measures. If the health facility does not meet $\geq$ 6 of the Ten Steps, the facility loses its certification.

Data on the health facilities were obtained from the CAHD database. If a healthcare facility had a second assessment related to the current reassessment, the

Figure 1 Coordination of Baby-Friendly Hospital Initiative in Turkey

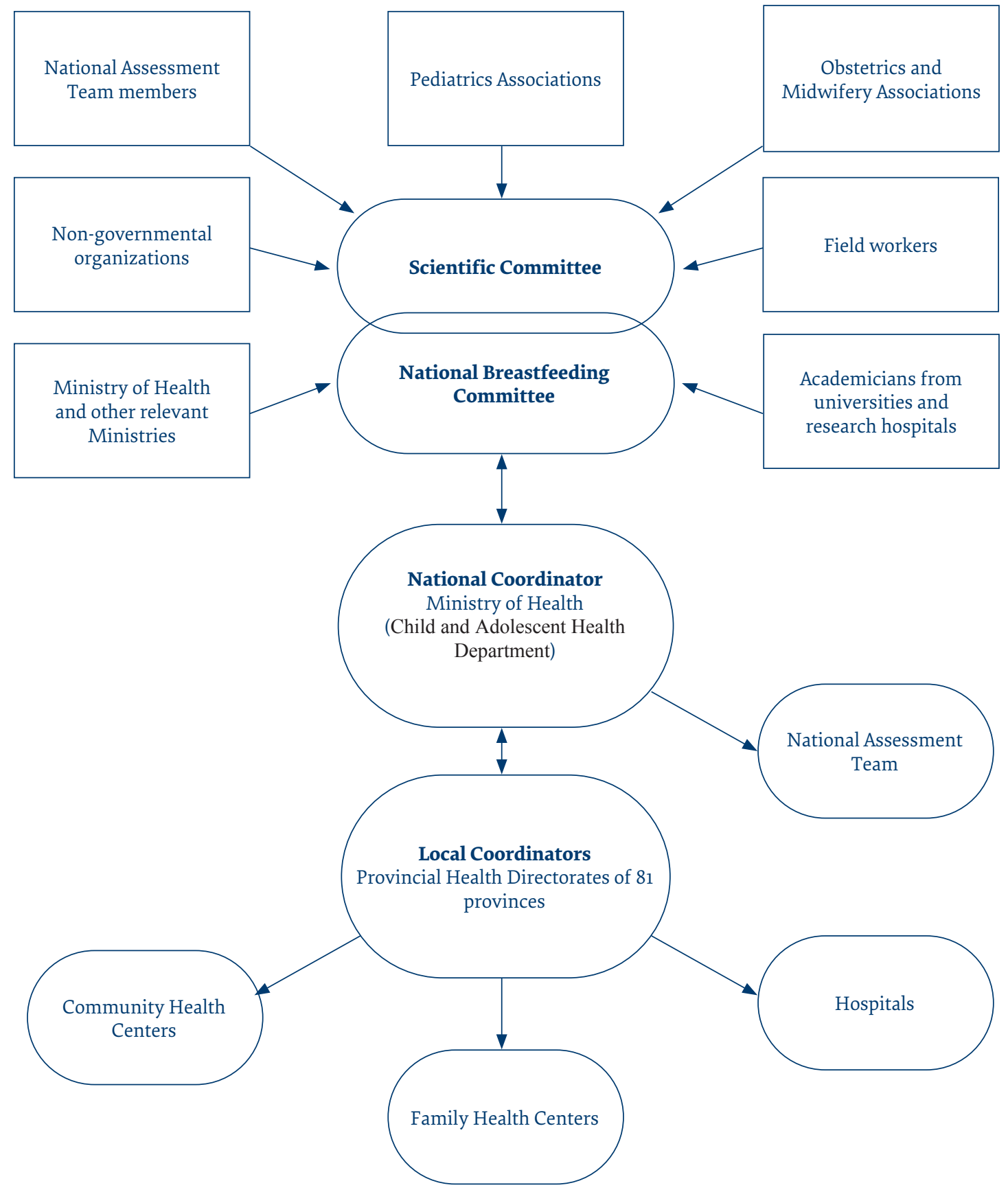


second was excluded (the second assessment evaluates corrective actions determined in the first reassessment). The database also gave information on whether the hospitals had a reassessment independent of the current reassessment within the past 5 years. Caesarean section delivery rates were divided into 4 quartiles to analyse factors associated with adherence for the Ten Steps. Hospitals were grouped to identify regional differences in compliance for the Ten Steps.

\section{Ethics}

The study was approved by the Hacettepe University Faculty of Medicine Ethics Committee (2021/08-38) and official permission was obtained from the General Directorate of Public Health (August 23, 2017; 67414668020-E.778).

\section{Statistical analysis}

The data were analysed using SPSS version 23.0. Analyses included arithmetic mean and standard deviation for continuous variables and frequency and percentage distributions for categorical variables. The $\chi^{2}$ test and Fisher's exact test were used for group comparisons. The Type I error was preset at 0.05 for all analyses.

\section{Results}

A total of 426 baby-friendly hospital reassessments were found in the database between 1 January 2018 and 31 December 2019. Second assessments related to the current reassessment $(n=11)$ and missing data $(n=1)$ were excluded from the study. As a result, 414 hospital reassessments were included: 232 (56.0\%) private hospitals; 116 (28.0\%) secondary care public hospitals; 38 (9.2\%) university hospitals; and 28 (6.8\%) tertiary care public hospitals.

It was determined that 767249 babies were born in these 414 hospitals in the year before the reassessment, which accounted for $30.1 \%$ of total deliveries in Turkey in 2017 and 2018. The distribution of hospitals by region was: west, 159 (38.4\%); south, 75 (18.1\%); central, 72 (17.4\%); north, $30(7.2 \%)$; and east, $78(18.8 \%)$ (Table 3). The time interval between initial certification and current reassessment (certification time) was $>10$ years in 234 (56.5\%) hospitals. The median certification time was 12 (326) years. The median percentage of caesarean deliveries was $63.1 \%(5.7-96.5 \%)$. Sixty-eight $(16.4 \%)$ of the hospitals had another external reassessment, independent of the current reassessment, within 5 years (Table 3).

The results show that adherence to the Ten Steps ranged from $81.6 \%$ to $98.1 \%$ (Figure 2). Only $252(60.1 \%)$ BFHs fulfilled all of the Ten Steps. Step 3, which ensures breastfeeding training and counselling in pregnancy, and Step 2, which includes training of healthcare staff, had the lowest compliance rates (81.6\% and $85.7 \%$ respectively). Steps $1(86.0 \%), 5(87.7 \%)$ and $10(88.2 \%)$ had the next lowest adherence rates. Step 8 (breastfeeding on demand; responsive feeding) and Step 7 (allowing mothers and infants to remain together 24 hours a day) had the highest adherence rates ( $98.1 \%$ and $97.1 \%$ respectively).
Factors associated with the rate of compliance with clinical practices (Steps 3-10) in BFHs are shown in Table 3. Full adherence rates for the clinical practices were $74.1 \%$ in tertiary care public hospitals, $67.2 \%$ in secondary care public hospitals, $64.2 \%$ in private hospitals and $60.5 \%$ in university hospitals. Adherence rates for all the clinical practices were higher in the west region than other regions. This association was significant for Steps $3,5,6,8$ and 10 and for full implementation of the clinical practices. Hospitals with caesarean section rates in the fourth quartile had lower adherence to Steps 3 and 10 than those with caesarean section rates in the lower quartiles. These hospitals also had lower full implementation rate of the clinical practices (55.3\%).

Hospitals that had an external reassessment within 5 years had higher compliance rates for all the clinical practices except Step 9, than those that did not have a reassessment. This association was significant for Step 3 and for full implementation of the clinical practices. Hospitals that fully implemented the management procedures had a significantly higher fulfilment rate for all clinical practices, separately and collectively.

Extensions of time (3-6 months) were granted to 151 (36.5\%) hospitals that had $\leq 5$ steps pending. At the end of the period, all hospitals had corrected their practices. Eleven $(2.7 \%)$ BFHs that did not meet $\geq 6$ of the Ten Steps lost their certification. Of those, $7(63.6 \%)$ were private hospitals, 1 (9.1\%) was a secondary care public hospital, $2(18.2 \%)$ were university hospitals and $1(9.1 \%)$ was a tertiary care public hospital. The certification process was restarted for these 11 hospitals.

\section{Discussion}

This study examined adherence to the Ten Steps in BFHs in Turkey after certification. The hospitals comprised more than a third of $\mathrm{BFHs}$, and therefore provide a largescale baseline. Our study revealed that $60.1 \%$ of the hospitals met all of the Ten Steps. Steps 3 and 2 had the lowest compliance rates, and Steps 8 and 7 had the highest rates. One of the key findings was that the presence of an external reassessment within 5 years was associated with higher adherence to Step 3, and full implementation of the clinical practices. The main objectives of a national BFHI are to increase coverage and maintain practices gained over time (14). The critical question is how to sustain standards $(2,5,15)$. Recent revised guidance for BFHI contains a call on countries to implement key responsibilities for sustainability (5). One of the responsibilities is to "utilize external assessment systems to regularly evaluate adherence to the Ten Steps" (5). Regular monitoring provides an opportunity for health facilities to take timely corrective action (5,14). However, establishing reassessment mechanisms has been a major challenge (15-17). A recent WHO report shows that only half of the countries with an active BFHI have a reassessment process and most of these occur less frequently than every 5 years (15). In Turkey, external reassessments have been made since the BFHI started, but these reassessments 


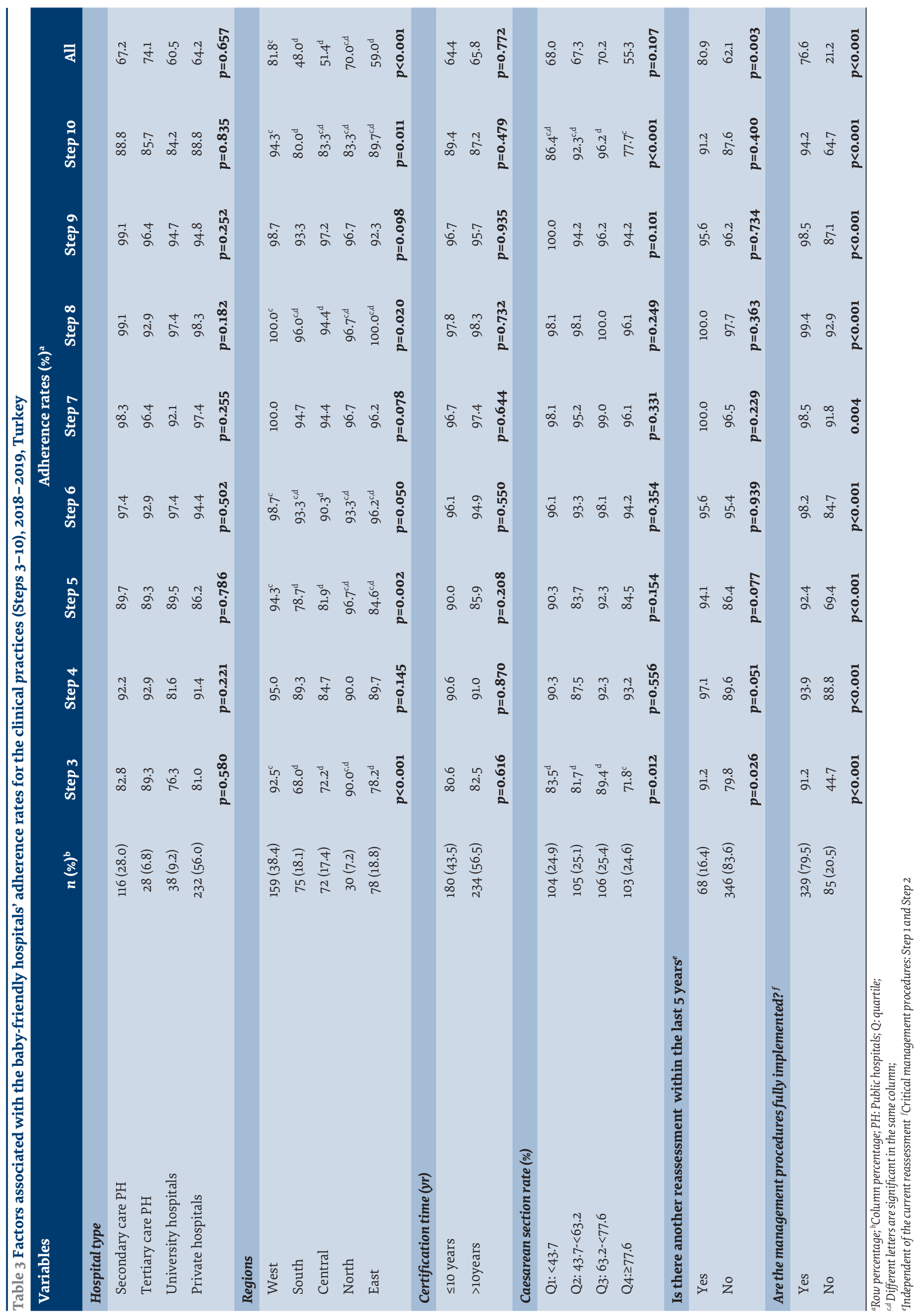




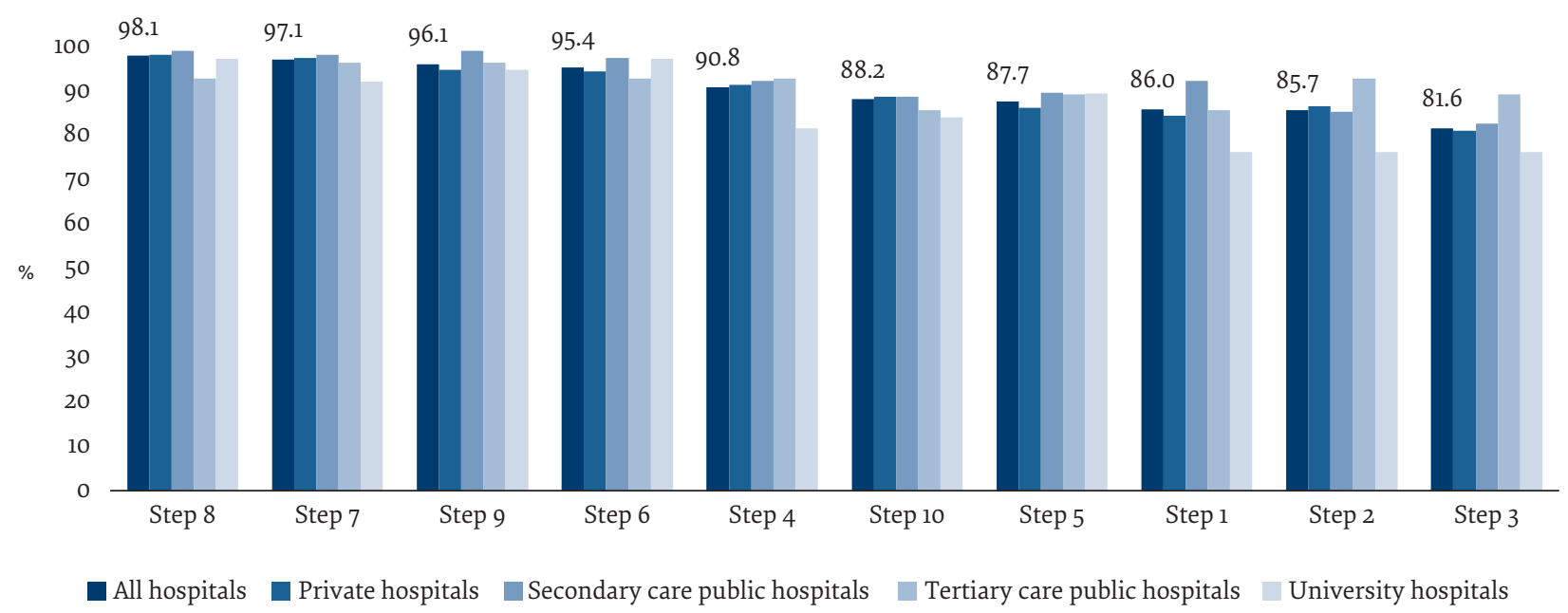

Note: The Steps are ordered from high to low according to the compliance rates of all hospitals.

could not be realized regularly. In the current study, approximately only one-sixth of BFHs included in the study had an external reassessment within the last 5 years. A recently conducted domestic study shows that the large number of health facilities in Turkey is one of the major challenges of the BFHI (18). The main interventions to address this challenge have been adding new assessors to the team and initiation of an interprovincial external assessment strategy (18).

Our study shows that there were regional variations in compliance with the Ten Steps. Adherence rates for the clinical practices were higher in the west than other regions separately and as a whole. Changes in culture and differences in the programme adoption may be possible causes of the regional differences. However, it is not possible to identify the causes of these variations in the current study, although the study highlights the need for further studies to examine regional factors affecting adoption of BFHI.

Caesarean delivery rate in Turkey is among the highest in the world (14.3\% in 1993, increased to $54.9 \%$ in 2018) $(19,20)$. Studies have reported a positive relationship between caesarean delivery and suboptimal breastfeeding practices $(21,22)$. The use of general anaesthesia, delay in the recovery due to surgical procedures, postoperative routines that disrupt mother-infant interaction, delay in skin-to-skin contact and delay in initiation of breastfeeding are suggested as possible causes $(21,23)$. All these reasons increase the frequency of giving a food/ liquid other than breast milk. Five strategies have been proposed that could improve breastfeeding outcomes after caesarean delivery: (1) supportive practices (skinto-skin contact, administration of regional anaesthesia, additional lactation support); (2) training of medical staff to support breastfeeding; (3) removal of physical barriers to skin-to-skin contact and early initiation of breastfeeding; (4) education about caesarean delivery and breastfeeding; and (5) reducing caesarean deliveries other than medically indicated $(21,24)$. The current study found that a caesarean section rate in the fourth quartile was associated with lower adherence to Steps 3 and 10, compared to lower caesarean section quartiles. Hospitals with caesarean delivery rates in the fourth quartile had lower adherence rates to Step 5 and the full implementation of clinical practices, but this change was not significant. Due to the effects of mode of delivery and maternal health on breastfeeding, WHO recommends integrating mother-friendly practices into the Ten Steps $(7,25,26)$. The Turkish Ministry of Health initiated the Mother-Friendly Hospital Programme in 2015 to solve problems including high caesarean section rates and women's rights issues (27). Baby-friendly practices is one of the prerequisites of the programme (27). The number of mother-friendly hospitals reached 79 at the end of 2020 (28). Mother-friendly and baby-friendly practices can create a synergetic effect in preventing increased caesarean section rates and related breastfeeding problems $(26,27)$.

Previous research has evaluated adherence to the Ten Steps in BFHs (29-33). A study conducted in Switzerland monitored $28 \mathrm{BFHs}$, and assessed adherence rates to Steps 4, 6, 7 and 9, and related breastfeeding indicators. Although $97 \%$ of infants were initially breastfed, only $38 \%$ of newborns were exclusively breastfed during their stay in hospital (29). A study performed in Brazil, and reassessing the $167 \mathrm{BFHs}$, found that $137(82 \%)$ met all of the Ten Steps. Those results are largely similar to our results, and show that Steps 3 and 2 had the lowest compliance rates, and Steps 7 and 9 the highest (30). A study in Accra, Ghana, of $6 \mathrm{BFHI}$ facilities, found poor adherence to BFHI (31). A recent study in Brazil compared the consistency of hospitals' self-monitoring and external reassessments (32), and found that the self-monitoring partially fulfilled its role of improving rates of adherence to BFHI criteria. The authors concluded that the self-monitoring failed to achieve the expected progress in Steps 4 and 6; possibly due to increased caesarean rates. 
In our study, Step 3 had the greatest adherence difficulty, as reported previously $(5,30,33,34)$. Step 3 requires baby-friendly facilities to offer counselling and training services to all pregnant women and their families about breastfeeding (5). Prenatal interventions, alone or in combination with intrapartum and/or postpartum support, can positively affect breastfeeding outcomes (34). Breastfeeding information can be delivered through individual or group sessions at prenatal clinics. Interpersonal breastfeeding support includes home visits, telephone support, and novel web-based formats that allow mothers to connect with their peers (34). In Turkey, in addition to informing pregnant women at routine antenatal care visits about breastfeeding, pregnancy information classes and pregnancy schools in health facilities are initiatives that have contributed to Step 3. By the end of 2020, training/consulting services were provided in 419 pregnant women schools and 1080 information classes (28).

The current study found that Steps 2 and 1 were the second and third most challenging steps for BFHs. Step 1 deals with a written baby feeding policy, continuous monitoring of clinical practice and full compliance with the Code. Compliance with the Code is important for facilities, since the promotion of breast milk substitutes is one of the largest interrupting factors for breastfeeding (35). Step 2 ensures that staff have sufficient up-todate knowledge, competence and skills to support breastfeeding. Steps 1 and 2 are crucial to be baby-friendly because the other 8 clinical practices are built on these steps (5). As shown in our study, the 8 clinical practice steps are more likely to be carried out if a hospital maintains the requirements of Steps 1 and 2 (5).
The strength of this study was that it provided a largescale baseline for monitoring the BFHI. However, it also had several limitations. Standard questionnaires and forms were used, and a limited number of independent variables were included in the analysis. There may be other variables (attitudes of health professionals and hospital managers, characteristics of the mothers and families, cultural features etc.) associated with the Ten Steps that are not included in the study. Another limitation of the study was that we did not include breastfeeding indicators since there may be bias in breastfeeding rates obtained from a hospital's own records. While the external evaluation results of hospitals are archived by the Ministry of Health, self-assessment results are not collected. Thus, another limitation of the study was that we could not evaluate effectiveness of self-assessment.

\section{Conclusions}

According to our results, reassessments seem useful. Full compliance with critical management procedures was associated with higher adherence to the clinical practices. Measures should be taken to address the difficulties that high caesarean rates may cause, and additional support should be provided to mothers who give birth by caesarean section. Since the mother-friendly hospital programme focuses on improving the conditions that negatively affect breastfeeding, it is important to implement it simultaneously with the BFHI. Integration of the Ten Steps into national policy documents and standards of care can help in the sustainability of the BFHI. Regional differences should be taken into account when implementing the programme. Further studies are needed to examine the factors that may affect sustainability of BFHI.

\section{Acknowledgement}

The authors gratefully acknowledge the many health care professionals and national assessment team members in the field who contributed to the reassessment of hospitals.

Funding: None

Competing interests: None declared.

\section{Hôpitaux amis des bébés en Turquie : évaluation de la conformité aux 10 étapes pour un allaitement maternel réussi \\ Résumé}

Contexte: L'Initiative Hôpitaux Amis des Bébés (IHAB) est un programme mondial conjoint de l'Organisation mondiale de la Santé et du Fonds des Nations Unies pour l'enfance visant à protéger, promouvoir et soutenir l'allaitement maternel. La pérennité des normes IHAB est importante tant pour les établissements de santé que pour leur mise en œuvre au niveau national.

Objectifs : Analyser les résultats de la réévaluation externe de l'Initative IHAB en Turquie pour la période 2018-2019.

Méthodes: Nous avons inclus 414 hôpitaux amis des bébés. Les 10 étapes pour un allaitement maternel réussi ont été divisées en deux groupes: procédures administratives essentielles (étapes 1 et 2 ) et pratiques cliniques essentielles (étapes 3 à 10). 
Résultats: Les 10 étapes ont été respectées par 60,1\% des hôpitaux. Les étapes 3 et 2 présentaient les taux de conformité les plus faibles (81,6\% et $85,7 \%$ ), et les étapes 7 et 8 affichaient les taux les plus élevés (97,1\% et 98,1\%). Les taux de césariennes dans le quatrième quartile étaient associés à un taux de conformité significativement plus faible aux étapes 3 et 10. L'existence d'une autre réévaluation externe dans les cinq ans était associée à un taux de conformité à l'étape 3 considérablement plus élevé et à un taux de mise en œuvre complète significativement plus élevé pour les pratiques cliniques. Les hôpitaux qui ont pleinement mis en œuvre les procédures administratives ont affiché un pourcentage de conformité nettement plus élevé pour toutes les pratiques cliniques. La région occidentale présentait des taux de conformité plus élevés pour toutes les pratiques cliniques par rapport aux autres régions.

Conclusion : Les réévaluations semblent utiles pour la pérennité du programme. Le respect total des étapes 1 et 2 est important pour une plus grande conformité aux étapes cliniques. Les variations régionales devraient être prises en compte dans la mise en œuvre du programme.

\section{المستشفيات الملائمة للأطفال في تر كيا: تقييم الالتزام بالخطو ات العشر للرضاعة الطبيعية الناجحة نيلجون شيلان، مالك كيليتش، صديقة يلتشين، باشاك تيزل، فاتح كارا}

$$
\begin{aligned}
& \text { الخلاصة }
\end{aligned}
$$

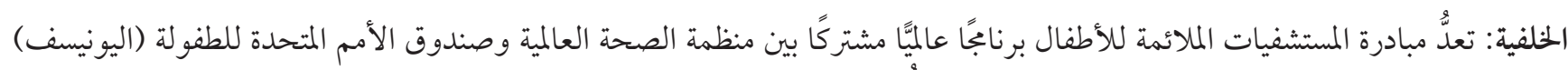

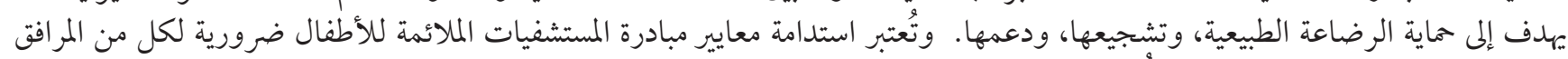

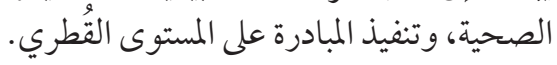

$$
\begin{aligned}
& \text { الأهداف: هدفت هذه الدر اسة الى تحليل نتائج إعادة التقييم الخارجي للمستشفيات الملائمة للأطفال في تركيا للثنائية } 180 \text { 2-19 } 20 .
\end{aligned}
$$

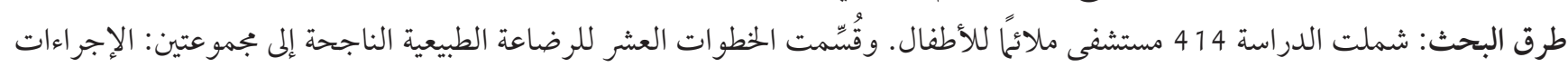

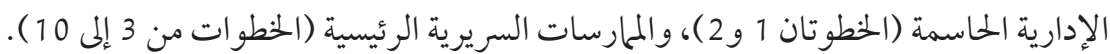

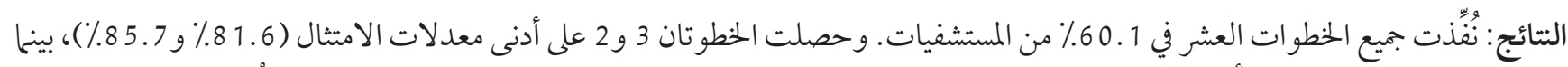

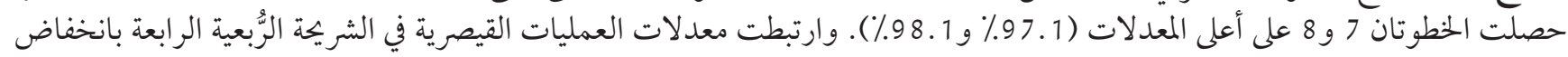

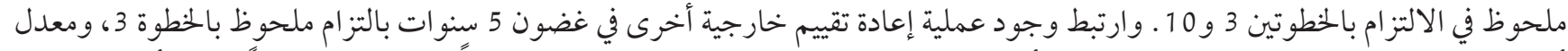

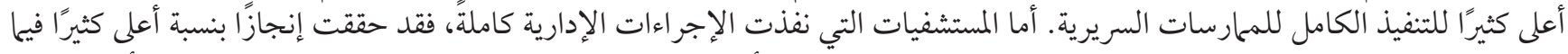

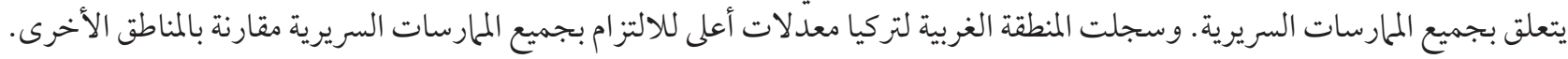

$$
\begin{aligned}
& \text { الاستنتاجات: من الو اضح أن إعادة التقييم مفيدة للاستدامة، وأنه من المهم الامتثال الكامل للخطوتين } 1 \text { و } 2 \text { لزيادة الالتزام بالخطوات التئن السريرية. }
\end{aligned}
$$

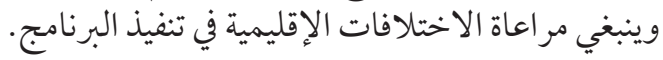

\section{References}

1. Jones G, Steketee RW, Black RE, Bhutta ZA, Morris SS, Bellagio Child Survival Study Group. How many child deaths can we prevent this year? Lancet. 2003 Jul 5;362(9377):65-71. https://doi.org/10.1016/S0140-6736(03)13811-1 PMID:12853204

2. Victora CG, Bahl R, Barros AJ, França GV, Horton S, Krasevec J, et al. Breastfeeding in the 21st century: epidemiology, mechanisms, and lifelong effect. Lancet. 2016 Jan 30;387(10017):475-90. https://doi.org/10.1016/So140-6736(15)01024-7 PMID:26869575

3. Rollins NC, Bhandari N, Hajeebhoy N, Horton S, Lutter CK, Martines JC, et al. Why invest, and what it will take to improve breastfeeding practices? Lancet. 2016 Jan 30;387(10017):491-504. https://doi.org/10.1016/So140-6736(15)01044-2 PMID:26869576

4. Chowdhury R, Sinha B, Sankar MJ, Taneja S, Bhandari N, Rollins N, et al. Breastfeeding and maternal health outcomes: a systematic review and meta-analysis. Acta Paediatr. 2015 Dec;104(467):96-113. https://doi.org/10.1111/apa.13102 PMID:26172878

5. Implementation guidance: protecting, promoting and supporting breastfeeding in facilities providing maternity and newborn services: the revised baby-friendly hospital initiative. Geneva: World Health Organization; 2018 (https://apps.who.int/iris/hani dle/10665/272943, accessed 10 Juanuary 2022).

6. International Code of Marketing of Breast-Milk Substitutes. Geneva: World Health Organization; 1981 (https://apps.who.int/iris/ handle/10665/40382, accessed 10 January 2022).

7. Baby-Friendly Hospital Initiative: revised, updated and expanded for integrated care, Section 3, breastfeeding promotion and support in a baby-friendly hospital: a 20-hour course for maternity staff. Geneva: World Health Organization and UNICEF; 2009 (https://apps.who.int/iris/bitstream/handle/10665/43593/9789241594981_eng.pdf;sequence=5, accessed 10 January, 2022).

8. Saadeh RJ. The Baby-Friendly Hospital Initiative 20 years on: facts, progress, and the way forward. J Hum Lact. 2012 Aug;28(3):272-5. https://doi.org/10.1177/0890334412446690 PMID:22723528 
9. Pérez-Escamilla R, Martinez JL, Segura-Pérez S. Impact of the Baby-friendly Hospital Initiative on breastfeeding and child health outcomes: a systematic review. Matern Child Nutr. 2016 Jul;12(3):402-17. https://doi.org/10.1111/mcn.12294 PMID:26924775

10. Renfrew M, Craig D, Dyson L, McCormick F, Rice S, King S, et al. Breastfeeding promotion for infants in neonatal units: a systematic review and economic analysis. Health Technol Assess. 2009 Aug;13(40):1-146. https://doi.org/10.3310/hta13400 PMID:19728934

11. Çaylan N, Yalçın SS. Status of breastfeeding in Turkey and the world: recommendations for the promotion of breastfeeding. Başkan S, editor. Çocuk Beslenmesi. Ankara: Türkiye Klinikleri; 2020:4-11.

12. Hacettepe University, Institute of Population Studies. Turkey Demographic and Health Surveys 1993-2018, Ankara, Turkey. (http://www.hips.hacettepe.edu.tr/en/menu/demographic_and_health_survey_serie-101. accessed 10 May 2022).

13. Baby-Friendly Hospital Initiative: revised, updated and expanded for integrated care, section 5, external assessment and reassessment. Geneva: World Health Organization and UNICEF; 2009.

14. Merten S, Dratva J, Ackermann-Liebrich U. Do baby-friendly hospitals influence breastfeeding duration on a national level? Pediatrics. 2005 Nov;116(5):e702-8. https://doi.org/10.1542/peds.2005-0537 PMID:16263985

15. National implementation of the Baby-friendly Hospital Initiative 2017. Geneva: World Health Organization; 2017 (Licence: CC BY-NC-SA 3.o IGO) (https://apps.who.int/nutrition/publications/infantfeeding/bfhi-national-implementation2017/en/index. html, accessed 10 January 2022).

16. Semenic S, Childerhose JE, Lauzière J, Groleau D. Barriers, facilitators, and recommendations related to implementing the Baby-Friendly Initiative (BFI); an integrative review. J Hum Lact. 2012 Aug;28(3):317-34. https://doi.org/10.1177/0890334412445195 PMID:22628290

17. Mydlilova A, Sipek A, Vignerova J. Breastfeeding rates in baby-friendly and non-baby-friendly hospitals in the Czech Republic from 2000 to 2006. J Hum Lact. 2009 Feb;25(1):73-8. https://doi.org/10.1177/0890334408325820 PMID:19020285

18. Çaylan N, Kılıç M, Tetik BK, Armut C, Tezel B. Breastfeeding promotion and baby-friendly health facilities in Turkey: a systematic approach to scale up the program. Ankara Med J. 2019;19(1):32-40. https://doi.org/10.17098/amj.542159

19. Santas G, Santas F. Trends of caesarean section rates in Turkey. J Obstet Gynaecol. 2018 Jul;38(5):658-62. https://doi.org/10.1080/ 01443615.2017.1400525 PMID:29519178

20. Republic of Turkey Ministry of Health, health statistics year book 2018. Ankara: Ministry of Health; 2019 (https://ohsad.org/ wp-content/uploads/2020/01/SB_istatistik-ylllı̆g-2018_en.pdf, accessed 10 January 2022).

21. Prior E, Santhakumaran S, Gale C, Philipps LH, Modi N, Hyde MJ. Breastfeeding after cesarean delivery: a systematic review and meta-analysis of world literature. Am J Clin Nutr. 2012 May;95(5):1113-35. https://doi.org/10.3945/ajcn.111.030254 PMID:22456657

22. Yalçın SS, Çaylan N, Yalçın S, Eryurt MA. Trends and determinants of prelacteal feeding in Turkey: analysis of 2003-2018 demographic and health surveys. Public Health Nutr. 2020 Dec;23(18):3269-82. https://doi.org/10.1017/S1368980020002037 PMID:32753087

23. Chang ZM, Heaman MI. Epidural analgesia during labor and delivery: effects on the initiation and continuation of effective breastfeeding. J Hum Lact. 2005 Aug;21(3):305-14. Kttps://doi.org/10.1177/0890334405277604 PMID:16113019

24. Kuyper E, Vitta B, Dewey K. Implications of cesarean delivery for breastfeeding outcomes and strategies to support breastfeeding. Alive Thrive Tech Brief. 2014;8:1-9.

25. Infant and young child feeding: a tool for assessing national practices, policies and programmes. Geneva: World Health Organization; 2003 (https://apps.who.int/iris/handle/10665/42794, accessed 10 January 2022).

26. The prevention and elimination of disrespect and abuse during facility-based childbirth: WHO statement. Geneva: World Health Organization; 2015 (WHO/RHR/14.23; https://apps.who.int/iris/bitstream/handle/10665/134588/WHO_RHR_14.23_eng.pdf, acn cessed 10 January 2022).

27. Erbaydar N. Mother-Friendly Hospital Programme of Turkey: national intervention to improve the quality of maternity services. East Mediterr Health J. 2021 Feb 25;27(2):202-10. https://doi.org/10.26719/emhj.20.138 PMID:33665805

28. Ministry of Health of the Republic of Turkey, Budget Presentation for 2021. Turkish Grand National Assembly, Plan and Budget Commission Meeting. Budget Presentation for 2021; Ankara. 18th November 2020. (https://sgb.saglik.gov.tr/ Eklenti/39387/0/2021planbutcesunumupdf.pdf, accessed 19 July 2021).

29. Merten S, Ackermann-Liebrich U. Exclusive breastfeeding rates and associated factors in Swiss baby-friendly hospitals. J Hum Lact. 2004 Feb;20(1):9-17. https://doi.org/10.1177/0890334403261017 PMID:14974696

30. Moura de Araujo MdF, Soares Schmitz BdA. Reassessment of baby-friendly hospitals in Brazil. J Hum Lact. 2007 Aug;23(3):24652. https://doi.org/10.1177/0890334407303899 PMID:17666535

31. Aryeetey RNO, Antwi CL. Re-assessment of selected Baby-Friendly maternity facilities in Accra, Ghana. Int Breastfeed J. 2013;8(1):15. https://doi.org/10.1186/1746-4358-8-15

32. Araújo RG, de Matos Fonseca V, de Oliveira MIC, Ramos EG. External evaluation and self-monitoring of the Baby-friendly Hospital Initiative's maternity hospitals in Brazil. Int Breastfeed J. 2019;14:1. https://doi.org/10.1186/s13006-018-0195-4

33. Zakarija-Grković I, Boban M, Janković S, Ćuže A, Burmaz T. Compliance with WHO/UNICEF BFHI standards in Croatia after implementation of the BFHI. J Hum Lact. 2018 Feb;34(1):106-15. https://doi.org/10.1177/0890334417703367 PMID: 28602147 
34. Wouk K, Tully KP, Labbok MH. Systematic review of evidence for baby-friendly hospital initiative step 3: prenatal breastfeeding education. J Hum Lact. 2017 Feb;33(1):50-82. https://doi.org/10.1177/0890334416679618 PMID:28135481

35 Piwoz EG, Huffman SL. The impact of marketing of breast-milk substitutes on WHO-recommended breastfeeding practices. Food Nutr Bull. 2015 Dec;36(4):373-86. https://doi.org/10.1177/0379572115602174 PMID:26314734 